\title{
Korelasi antara Neutrophil-Lymphocyte Ratio dan NT-proBNP pada Pasien Gagal Jantung Anak Akibat Penyakit Jantung Rematik
}

Syahradian Hasbrima, Sri Endah Rahayuningsih, Dany Hilmanto

Departemen Ilmu Kesehatan Anak Fakultas Kedokteran Universitas Padjadjaran/RSUP Dr. Hasan Sadikin, Bandung

Latar belakang. Penyakit jantung rematik (PJR) merupakan penyebab paling sering gagal jantung anak didapat terutama di negara berkembang. Pemeriksaan penanda gagal jantung seperti $N$-terminal pro brain natriuretic peptide (NT-proBNP) dapat membantu dalam melakukan diagnosis. Neutrophil-lymphocyte ratio (NLR) merupakan penanda inflamasi yang mudah dilakukan dan sudah digunakan dalam berbagai penyakit kronis. Tujuan. Mengetahui korelasi antara nilai NLR dengan kadar NT-proBNP pada pasien gagal jantung anak akibat PJR.

Metode. Penelitian analitik observasional dengan studi potong lintang. Data berasal dari register gagal jantung anak akibat penyakit jantung rematik Divisi Kardiologi Departemen/KSM Ilmu Kesehatan Anak RSUP Dr. Hasan Sadikin Bandung Tahun 2020 dan sampel BBT penelitian sebelumnya. Populasi penelitian ini adalah anak berusia $<18$ tahun yang memenuhi kriteria inklusi. Kadar NT-proBNP diperiksa menggunakan ELISA Kit Elabscience Catalog No: E-EL-H0902. Analisis korelasi dilakukan dengan menggunakan uji korelasi Spearman dengan aplikasi SPSS 22.

Hasil. Total subjek penelitian 34 anak dengan usia median 14 tahun. Subjek penelitian paling banyak terdapat pada kelompok usia 11-<16 tahun (65\%). Sebanyak 23 (67\%) subjek berada pada derajat gagal jantung ringan berdasarkan klasifikasi NYHA kelas I-II. Keterlibatan katup paling banyak mencakup kerusakan katup mitral dan aorta. Peningkatan kadar NT-proBNP terdapat pada 18 subjek (53\%). Rata-rata nilai NT-proBNP adalah 388,09 pg/ml (20-2500 pg/ml) dan NLR 1,79 (0,57-5,27). Hasil analisis korelasi antara NLR dan NT-proBNP menunjukkan tidak terdapat korelasi dengan nilai $\mathrm{r}=0,054(\mathrm{p}=0,382)$.

Kesimpulan. Penelitian ini tidak menemukan korelasi antara nilai NLR dan kadar NT-proBNP pada pasien gagal jantung anak akibat PJR. Sari Pediatri 2021;23(3):191-6

Kata kunci: gagal jantung, penyakit jantung rematik, anak, rasio neutrofil-limfosit, NT-proBNP

\section{Correlation between Neutrophil-Lymphocyte Ratio and NT-proBNP in Heart Failure Children Due to Rheumatic Heart Disease}

Syahradian Hasbrima, Sri Endah Rahayuningsih, Dany Hilmanto

Background. Rheumatic heart disease (RHD) is the most common etiology of heart failure in children found mostly in developing countries. An assessment of heart failure biomarkers such as N-terminal pro-brain natriuretic peptide (NT-proBNP) can help the diagnosis. The Neutrophil-lymphocyte ratio (NLR) is a useful inflammatory marker in various chronic diseases, including heart failures.

Objective. To find out the correlation between the value of NLR and NT-proBNP in heart failure children due to RHD.

Methods. An analytical observational cross-sectional study. Data come from the registration of pediatric Heart Failure due to RHD in a cardiology division in Child Health Department at Dr. Hasan Sadikin General Hospital (RSHS) in Bandung in the year 2020 and blood samples from a previous study. The population of this study is children aged $<18 \mathrm{yr}$ who met the inclusion criteria. The value of NT-proBNP was examined using ELISA Kit Elabscience Catalogue No: E-EL-H0902. A correlation analysis was conducted by Spearman Correlation test using an SPSS 22 application.

Result. The total subjects of this study are 34 children with a median age of 14 years old. The majority of study subjects are found in the age group of $11-<16$ years old (65\%). A total number of 23 subjects (67\%) are detected as having a mild heart failure category based on NYHA class I-II classification. The heart valve involvements mostly affect mitral and aortic valves. The increase in the rate of NT-proBNP is found in 18 subjects (53\%). The mean NT-proBNP are 388,09 pg/ml (20-2500 pg/ml) and NLR 1,79 (0,57-5,27). The result shows no correlation between NT-proBNP and NLR with $\mathrm{r}=0.054(\mathrm{p}=0.382)$.

Conclusion. This study finds no correlation between the value of NLR and NT-proBNP among heart failure children due to RHD. Sari Pediatri 2021;23(3):191-6

Keywords: heart failure, rheumatic heart disease, children, neutrophil-lymphocyte ratio, NT-proBNP

Alamat korespondensi: Sri Endah Rahayuningsih. Departemen Ilmu Kesehatan Anak Fakultas Kedokteran UNPAD. Rumah Sakit Hasan Sadikin Bandung. Jl. Pasteur 38 Kode Pos 40161. Email: seraning@yahoo.com 
$\mathrm{P}$ enyakit jantung reumatik (PJR) merupakan penyebab paling sering penyakit jantung didapat pada anak dan dewasa muda, terutama di negara berkembang. Angka kejadian terutama meningkat pada usia 5-15 tahun, dengan estimasi terdapat 470.000 kasus baru setiap tahunnya. ${ }^{1,2}$ Tahun 2015, Indonesia tercatat sebagai negara ke-4 dengan jumlah kasus PJR terbanyak di dunia, setelah India, Cina, dan Pakistan. ${ }^{3}$

Demam reumatik akut (DRA) terjadi akibat interaksi kompleks antara infeksi Streptokokus grup A, faktor inang, dan lingkungan. ${ }^{4}$ Salah satu manifestasi klinis dari DRA yang menyebabkan morbiditas dan mortalitas jangka panjang ialah karditis. Demam rematik disebabkan oleh infeksi bakteri pada tenggorokan yang tidak mendapat terapi adekuat disertai faktor risiko lingkungan sosioekonomi rendah yang menyebabkan terjadinya infeksi berulang. ${ }^{4,5}$ Serangan DRA berulang menyebabkan inflamasi berkepanjang sehingga terjadi kerusakan katup jantung menetap yang disebut sebagai PJR. ${ }^{6}$ Pada pasien PJR dapat terjadi peningkatan volume darah di ventrikel sehingga terjadi peregangan dinding ventirkel jantung akibat regurgitasi atau stenosis katup mitral dan aorta. Hal ini dapat menyebabkan gagal jantung pada pasien PJR. ${ }^{4}$

Diagnosis gagal jantung pada anak dilakukan melalui anamnesis, pemeriksaan fisis dan pemeriksaan penunjang. Derajat keparahan gagal jantung dinilai dengan menggunakan Klasifikasi Skor Ross dan New York Heart Association (NYHA). Namun demikian, metode ini memiliki kelemahan karena bersifat subjektif. Oleh karena itu, diperlukan suatu biomarker yang bersifat lebih objektif dalam menentukan tingkat keparahan gagal jantung yaitu $N$-terminal pro Brain Natriuretic Peptide (NT-proBNP). ${ }^{6}$ Hormon ini disekresi oleh kardiomiosit sebagai respon terhadap peregangan dinding ventrikel jantung. ${ }^{7}$ Pada jurnal yang dipublikasikan dalam American Heart Association (AHA) Journals 2020 menyebutkan bahwa hormon ini sudah digunakan secara luas dalam melakukan diagnosis pada kasus gagal jantung dewasa. ${ }^{8}$ Namun demikian, masih sedikit penelitian yang dilakukan pada populasi anak.

Neutrophil-lymphocyte ratio (NLR) adalah suatu penanda inflamasi baru yang telah digunakan dalam berbagai penyakit kronis. Derlene $\mathrm{dkk}^{9}$ melaporkan bahwa terdapat korelasi positif antara peningkatan nilai NLR dan kadar BNP pada populasi anak gagal jantung akibat kardiomiopati. ${ }^{10}$ Selain itu, peningkatan NLR sering kali didapatkan pada keadaan infeksi atau paska infeksi bakteri salah satunya pada infeksi Streptokokus.
Penelitian ini bertujuan untuk mengetahui apakah terdapat peranan yang sama antara NT-proBNP dan NLR dalam proses inflamasi pada pasien gagal jantung anak akibat PJR.

\section{Metode}

Penelitian ini adalah analitik observasional dengan rancangan potong lintang. Subjek penelitian adalah pasien anak yang terdaftar dalam register gagal jantung anak akibat PJR Divsi Kardiologi Departemen/KSM Ilmu Kesehatan Anak tahun 2020. Kriteria inklusi penelitian ini adalah anak berusia $>5$ tahun $-<18$ tahun dan diketahui telah terdiagnosis gagal jantung akibat PJR. Kriteria eksklusi adalah mengalami gangguan fungsi ginjal akut atau kronis, pasien sedang mengalami sepsis atau pneumonia, dan pasien dengan penyakit primer lain, seperti penyakit autoimun, penyakit jantung bawaan, keganasan, autoimun. Pemilihan subjek dipilih secara consecutive sampling, yaitu semua subjek memenuhi kriteria pemilihan dimasukkan ke dalam penelitian sampai jumlah subjek terpenuhi. Penelitian ini telah mendapatkan izin dari Komite Etik Penelitian Rumah Sakit Umum Pusat Dr Hasan Sadikin Bandung.

Data dicatat dari register terdiri dari usia, jenis kelamin, derajat keparahan gagal jantung berdasarkan klasifikasi NYHA, katup yang terlibat dan nilai NLR. Selanjutnya dilakukan pemeriksaan NT-proBNP dari bahan biologis tersimpan (BBT) penelitian sebelumnya yang berjudul "Korelasi antara nilai red cell distribution width (RDW) dengan Fungsi ventrikel kiri pada anak dengan gagal jantung akibat penyakit jantung rematik". Spesimen darah diberi nama, nomor rekam medis, dan nomor urut penelitian kemudian diperiksa di laboratorium Patologi Klinik RSHS menggunakan ELISA Kit Elabscience Catalog No: E-EL-H0902.

Karakteristik subjek penelitian dilakukan analisis univariabel dengan menyajikan ukuran statistik jumlah dan persentase untuk data kategorik, yaitu data jenis kelamin dan keterlibatan katup, sedangkan untuk data numerik dengan menyajikan ukuran statistik rata-rata, simpang baku, median, dan rentang yang terdiri atas data usia, kelas NYHA, NLR, dan NT-proBNP. Sebelum dilakukan analisis bivariabel dilakukan uji normalitas data dengan menggunakan uji normalitas Shapiro Wilk karena besar sampel kurang dari 50 orang. Kemudian analisis korelasi antara NLR dan NT-proBNP dilakukan 
dengan menggunakan uji korelasi rank Spearman. Interpretasi hasil uji hipotesis ditetapkan berdasarkan kekuatan korelasi, arah korelasi, dan nilai p. Analisis data dilakukan dengan menggunakan program statistical product and service solution (SPSS) for Windows versi 22.

\section{Hasil}

Terdapat total 35 subjek penelitian yang memenuhi kriteria inklusi. Satu subjek di ekslusi karena didapatkan kelainan defek septum ventrikel. Dengan demikian didapatkan jumlah sampel akhir sebanyak 34. Data karakteristik subjek penelitian tertera pada Tabel 1 . Dari Tabel 1 tampak median usia subjek penelitian 14 tahun. Sebanyak 56\% subjek penelitian berjenis kelamin laki-laki. Derajat keparahan gagal jantung yang dialami subjek penelitian berdasarkan klasifikasi NYHA paling banyak, yaitu NYHA kelas II (41\%). Sementara kelainan katup yang mencakup katup mitral dan aorta didapatkan pada $47 \%$ subjek penelitian.

Nilai median kadar NLR 1,18, sedangkan NTproBNP $192,5 \mathrm{pg} / \mathrm{ml}$. Hasil deskriptif statistik pemeriksaan keduanya tertera pada Tabel 2. Dari tabel tersebut hasil uji normalitas data diperoleh nilai $\mathrm{p}<0,001$ dan $\mathrm{p} 0,016$ yang artinya data tidak berdistribusi normal sehingga untuk perhitungan lebih lanjut digunakan uji statistik non parametrik menggunakan uji Spearman.

Pada Tabel 3 dapat dilihat perbandingan nilai NLR dan NT-proBNP dari berbagai karakteristik yang diteliti. Tampak dari hasil uji statistik perbedaan nilai NLR dan NT-proBNP dari semua karakteristik tidak bermakna $(\mathrm{p}>0,05)$. Tabel 4 menunjukkan hasil analisis korelasi antara rasio neutrofil-limfosit dengan NT-proBNP menunjukkan tidak terdapat korelasi dengan nilai koefisien korelasi 0,05 ( $p>0,05)$ yang tidak bermakna.

Berdasarkan pemeriksaan kadar NT-proBNP diperoleh 18 anak interpretasinya meningkat dan sisanya 16 anak tergolong normal. Hubungan karakteristik dengan hasil interpretasi kadar NT-proBNP tertera pada Tabel 5. Pada semua karakteristik yang diteliti tidak terdapat hubungan yang bermakna dengan hasil interpretasi NT-proBNP.

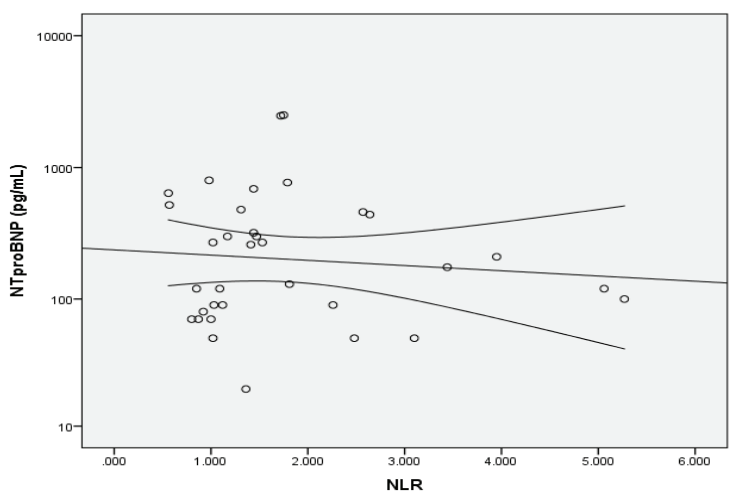

Gambar 1. Scatterplot NLR dengan NT-proBNP

Tabel 1. Karakteristik subjek penelitian

\begin{tabular}{lcc}
\hline Karakteristik & Jumlah & $\%$ \\
\hline Jenis kelamin & & \\
$\quad$ Laki-laki & 19 & 56 \\
$\quad$ Perempuan & 15 & 44 \\
Usia (tahun) & & \\
$\quad<5$ & 0 & 0 \\
$5-<11$ & 5 & 15 \\
$11-<16$ & 22 & 65 \\
$16-<18$ & 7 & 21 \\
Median : 14 & & \\
Rentang : 8-18 & & \\
NYHA : & & \\
Kelas 1 & 9 & 26 \\
Kelas 2 & 14 & 41 \\
Kelas 3 & 9 & 26 \\
Kelas 4 & 2 & 6 \\
Katup jantung yang terlibat & & \\
$\quad$ Mitral & 15 & 44 \\
Aorta & 3 & 9 \\
Mitral dan Aorta & 16 & 47 \\
\hline
\end{tabular}

Tabel 2. Deskriptif statistik rasio neutrofil-limfosit dan NT-probBNP

\begin{tabular}{lcccc}
\hline Variabel & \multicolumn{3}{c}{ Ukuran statistik } & \multirow{2}{*}{ Nilai p } \\
\cline { 2 - 4 } & Rata-rata (SD) & Median & Rentang & \\
\hline Rasio Neutrofil-limfosit & $1,79(1,18)$ & 1,18 & $0,57-5,27$ & $<0,001$ \\
NT-probBNP & $388,09(576,0)$ & 192,5 & $20-2500$ & 0,016 \\
\hline Ketrangan & & & &
\end{tabular}

Keterangan: *) berdasarkan uji Shapiro-Wilk 


\begin{tabular}{|c|c|c|c|c|}
\hline \multirow[b]{2}{*}{ Karakteristik } & \multicolumn{2}{|c|}{ NLR } & \multicolumn{2}{|c|}{ NT- probBNP } \\
\hline & Median (range) & Nilai $\mathrm{p}^{*}$ & Median (range) & Nilai $\mathrm{p}^{*}$ \\
\hline Jenis kelamin & & 0,167 & & 0,319 \\
\hline Laki-laki & $1,17(0,56-5,06)$ & & $260(50-2470)$ & \\
\hline Perempuan & $1,47(0,87-5,27)$ & & $120(20-2500)$ & \\
\hline Usia (tahun) & & 0,769 & & 0,939 \\
\hline$<5$ & 0 & & 0 & \\
\hline $5-<11$ & $1,17(0,57-5,27)$ & & $130(100-520)$ & \\
\hline $11-<16$ & $1,44(0,80-5,06)$ & & $192,5(20-2470)$ & \\
\hline $16-<18$ & $1,02(0,56-2,64)$ & & $270(50-2500)$ & \\
\hline NYHA: & & 0,176 & & 0,834 \\
\hline Kelas I & $1,02(0,85-2,26)$ & & $120(50-800)$ & \\
\hline Kelas II & $1,58(0,56-5,27)$ & & $285(50-2470)$ & \\
\hline Kelas III & $1,41(1,03-3,95)$ & & $210(20-2500)$ & \\
\hline Kelas IV & $3,04(2,64-3,44)$ & & $307,5(175-440)$ & \\
\hline Katup jantung yang terlibat & & 0,983 & & 0,267 \\
\hline Mitral & $1,31(0,56-5,27)$ & & $120(50-800)$ & \\
\hline Aorta & $1,17(1,02-2,26)$ & & $90(50-300)$ & \\
\hline Mitral dan aorta & $1,46(0,57-3,95)$ & & $280(20-2500)$ & \\
\hline
\end{tabular}

Keterangan: *) Nilai p dihitung berdasrakan uji Mann-Whitney (untuk karakteristik dua kategori), atau uji KruskalWallis (untuk karakateristik lebih dari dua kategori)

Tabel 4. Korelasi antara rasio neutrofil-limfosit dengan NT-probBNP

\begin{tabular}{lll}
\hline Korelasi antara & Koefisien Korelasi $\left.(\mathrm{r})^{*}\right)$ & Nilai $\mathrm{p}$ \\
\hline Rasio neutrofil-limfosit dengan & 0,054 & 0,382 \\
NT-probBNP & \\
\hline Keterangan : ${ }^{*}$ ) berdasarkan uji korelasi rank Spearman &
\end{tabular}

Keterangan : ${ }^{*}$ berdasarkan uji korelasi rank Spearman

Tabel 5. Hubungan karakteristik dengan interpretasi NT-proBNP

\begin{tabular}{|c|c|c|c|}
\hline \multirow[t]{2}{*}{ Karakteristik } & \multicolumn{2}{|c|}{ Interpretasi NT-proBNP } & \multirow[b]{2}{*}{ Nilai $\mathrm{p}$} \\
\hline & Meningkat & Normal & \\
\hline Jenis kelamin & & & 0,515 \\
\hline Laki-laki & 11 & 8 & \\
\hline Perempuan & 7 & 8 & \\
\hline Usia (tahun) & & & 0,815 \\
\hline $5-10$ & 2 & 3 & \\
\hline $11-15$ & 12 & 10 & \\
\hline $16-18$ & 4 & 3 & \\
\hline NYHA & & & 0,349 \\
\hline Kelas I & 3 & 6 & \\
\hline Kelas II & 8 & 6 & \\
\hline Kelas III & 5 & 4 & \\
\hline Kelas IV & 2 & 0 & \\
\hline Katup yang terlibat & & & 0,526 \\
\hline Mitral & 7 & 8 & \\
\hline Aorta & 1 & 2 & \\
\hline Mitral dan Aorta & 10 & 6 & \\
\hline
\end{tabular}

Keterangan : Nilai p dihitung dengan uji chi-square atau uji eksak Fisher jika nilai ekpektasi sel $<5$ 
Syahradian Hasbrima dkk: Korelasi antara NLR dan NT-proBNP pada pasien gagal jantung anak akibat PJR

\section{Pembahasan}

Penyakit jantung reumatik merupakan salah satu penyebab gagal jantung didapat yang paling sering terjadi pada anak di negara berkembang, dengan angka kejadian pada usia 5-15 tahun., ${ }^{2,11}$ Infeksi Streptokokus berulang menyebabkan inflamasi berkepanjangan sehingga meningkatkan risiko terjadinya kerusakan katup menetap pada usia remaja dan dewasa muda. ${ }^{12}$ Pada penelitian ini didapatkan 22 dari 34 subjek penelitian berada pada rentang usia 11-15 tahun, dengan usia median 14 tahun.

Berbagai faktor dapat memengaruhi tingkat keparahan gagal jantung akibat penyakit jantung rematik seperti usia yang lebih muda saat terdiagnosis, terapi yang tidak adekuat baik untuk eradikasi kuman maupun terapi profilakasis jangka panjang serta morfologi katup PJR yang berat sejak awal terdiagnosis. ${ }^{13}$ Penelitian ini sebagian besar melibatkan pasien PJR yang datang ke poliklinik rawat jalan sehingga pasien tidak dalam kondisi akut, $67 \%$ subjek penelitian tergolong dalam derajat keparahan gagal jantung ringan, yaitu kelas I dan II berdasarkan klasifikasi NYHA. Pada anamnesis juga didapatkan bahwa pasien tersebut memiliki kepatuhan pengobatan baik, yaitu mengonsumsi obat gagal jantung setiap hari, seperti furosemid dan kaptopril, serta eritromisin atau injeksi benzatine penisilin G setiap 28 hari bila tersedia.

Proses inflamasi yang terjadi akibat respon imun reaktivasi silang antara bakteri SGA dengan komponen katup jantung yang memiliki molecular mimicry dapat menyebabkan kerusakan menetap pada katup mitral, aorta ataupun keduanya. Regurgitasi mitral (RM) merupakan kelainan jantung paling dominan pada kasus DRA, yaitu terdapat pada hampir 95\% kasus DRA. ${ }^{4}$ Pada penelitian ini ditunjukkan 15 subjek dengan keterlibatan katup mitral, 16 subjek dengan keterlibatan katup mitral dan aorta serta sisanya 3 subjek dengan keterlibatan katup aorta saja.

Pada pasien anak dengan gagal jantung terjadi disfungsi ventrikel yang dapat menyebabkan myocardial injury sehingga terjadi peningkatan sitokin proinflamasi, seperti TNF- $\alpha$, interleukin- 6 , enzim proteolitik dan c-reactive protein (CRP). Inflamasi yang terjadi juga menyebabkan peningkatan jumlah leukosit terutama neutrofil. Sitokin yang juga dilepas oleh leukosit ini kemudian dapat merusak miokardium jantung dan menyebabkan penurunan fungsi fraksi ejeksi ventrikel. Selain itu, juga terjadi respon stres fisiologis yang menyebabkan aktivasi aksis-hipotalamus-pituitariadrenal sehingga terjadi peningkatan produksi kortisol dan katekolamin yang menyebabkan limfopenia. Peningkatan neutrofil disertai limfopenia akan menyebabkan peningkatan rasio neutrofil limfosit. ${ }^{14}$ Penelitian Durmus $\mathrm{dkk}^{14}$ melaporkan nilai NLR 3,0 dapat memprediksi gagal jantung dengan sensitivitas $86,3 \%$ dan spesifisitas $77,5 \%$. Selain itu, peningkatan NLR terutama didapatkan pada keadaan infeksi atau paska infeksi bakteri salah satunya pada infeksi Streptokokus. ${ }^{15}$ Penelitian Derlene $\mathrm{dkk}^{9}$ yang melaporkan adanya korelasi bermakna antara peningkatan NLR dengan NTproBNP melibatkan 57 pasien anak kardiomiopati dengan rerata fraksi ejeksi ventrikel kiri 35,5\%.

Hasil rerata nilai NLR 1,79 dengan rentang nilai cukup besar, yaitu 0,57-5,27. Selain itu, sebagian besar populasi penelitian merupakan pasien anak gagal jantung akibat PJR yang sedang tidak mengalami gejala akut atau asimtomatis. Pada penelitian sebelumnya, Giray $\mathrm{dkk}^{16}$ melaporkan bahwa nilai NLR pada pasien DRA dengan keterlibatan karditis lebih tinggi dibanding pasien sehat, yaitu rata-rata 1,81 vs 3,0 . Hal ini menunjukkan proses inflamasi yang lebih berat pada pasien DRA dengan karditis. Pada penelitian yang bertujuan mencari penanda inflamasi pada pasien DRA tersebut juga disebutkan bahwa pada DRA serangan pertama nilai NLR lebih tinggi bahkan pada pasien dengan karditis subklinis (tidak ditemukan suara bising jantung organik namun didapatkan kelainan katup khas rematik karditis) dibanding dengan pasien DRA tanpa keterlibatan jantung. ${ }^{16} \mathrm{Hal}$ ini juga disebabkan karena pada keadaan paska infeksi Strepotokokus terjadi granulosistosis mulai 15 jam dan limfopenia pada 6 jam paska infeksi.

Hormon NT-proBNP dilepas dari miokadium ventrikel jantung sebagai respon dari meningkatnya peregangan myocardial fiber baik akibat volume atau pressure overload. ${ }^{7,17}$ Oleh karena itu, NT-proBNP akan meningkat pada pasien gagal jantung. Menurut Rusconi dkk, ${ }^{18}$ kadar NT- proBNP $>1000 \mathrm{pg} / \mathrm{ml}$ sesuai dengan fungsional kelas III-IV NYHA yang menandakan gagal jantung derajat sedang hingga berat. Pada penelitian ini didapatkan kadar NT-proBNP rata-rata 388,09 pg/ml dengan rentang $20-2500 \mathrm{pg} / \mathrm{ml}$, hal ini sesuai dengan kondisi klinis subjek penelitian yang sebagian besar mengalami gagal jantung ringan.

Rata-rata kadar NLR dan NT-proBNP paling tinggi terdapat di kelompok anak dengan NYHA kelas IV (3,04 dan $307,5 \mathrm{pg} / \mathrm{ml}$ ) dan pada keterlibatan dua katup, yaitu mitral dan aorta (1,46 dan 280). Hal ini menyerupai hasil penelitian sebelumnya yang melaporkan bahwa 
peningkatan kadar NT proBNP terutama berkorelasi secara bermakna pada kondisi gagal jantung derajat sedang hingga berat atau anak dengan fungsional kelas III-IV..$^{18}$ Rusconi $\mathrm{dkk}^{18}$ melaporkan bahwa kadar NTproBNP $<450 \mathrm{pg} /$ $\mathrm{ml}$ menunjukkan keadaan asimtomatis pada anak gagal jantung, $\geq 1000 \mathrm{pg} / \mathrm{ml}$ menunjukkan kondisi gagal jantung dengan gejala berat, dan antara 450-1000 pg/ml sulit untuk membedakan kondisi pasien asimtomatis atau gejala minimal. Hasil penelitian tersebut menyimpulkan bahwa pada kadar NTproBNP $<1000$ pg/ml perlu dilakukan pemeriksaan serial untuk menentukan apakah pasien dalam kondisi dengan fungsi jantung yang terkontrol atau tidak.

Hasil analisis korelasi penelitian ini antara rasio neutrofil-limfosit dengan NT-proBNP menunjukkan tidak terdapat korelasi bermakna. Hal ini dapat disebabkan karena distribusi data yang tidak merata serta sebagian besar mengalami gagal jantung ringan dan tidak dalam kondisi akut.

\section{Kesimpulan}

Nilai NLR dan peningkatan kadar NT-proBNP tidak menunjukkan adanya korelasi yang bermakna pada pasien gagal jantung anak akibat penyakit jantung rematik. Namun demikian didapatkan bahwa rata-rata nilai NLR dan NT-proBNP paling tinggi terdapat pada kondisi gagal jantung berat (NYHA IV) dan pasien dengan keterlibatan dua katup yaitu mitral dan aorta. Penelitian lebih lanjut untuk menilai korelasi antara NLR dengan NTproBNP pada pasien gagal jantung anak akibat PJR perlu dilakukan dengan melibatkan sampel penelitian yang memiliki distribusi merata berdasarkan tingkat keparahan gagal jantung.

\section{Daftar pustaka}

1. Rothenbühler M, O’Sullivan CJ, Stortecky S, dkk. Active surveillance for rheumatic heart disease in endemic regions: A systematic review and meta-analysis of prevalence among children and adolescents. Lancet Glob Heal [Internet] 2014;2:e717-26.

2. Steer AA, Gibofsky A. Acute rheumatic fever : Epidemiology and pathogenesis. Diakses: 5 Oktober 2021. Didapat dari: https://www.uptodate.com.

3. Watkins DA, Johnson CO, Colquhoun SM, dkk. Global, Regional, and national burden of rheumatic heart disease,
1990-2015. N Engl J Med 2017;377:713-22.

4. Tani LY. Rheumatic fever and rheumatic heart disease. Dalam: Allen HD, Shaddy RE, Penny DJ, dkk, penyunting. Moss and Adams' heart disease in infants, children, and adolescents including the fetus and young adult. Edisi ke-9. Wolters Kluwer; 2017. h.1374-414.

5. Carapetis JR, McDonald M, Wilson NJ. Acute rheumatic fever. Lancet 2005;366:155-68.

6. Yasmien, Nova R, Saleh MI, Rhadiyanto KY. Correlation of heart failure severity and N-Terminal pro-brain natriuretic peptide level in children. Paediatr Indones 2016;56:315-9.

7. O'Connor MJ, Shaddy RE. Chronic heart failure in children. Dalam: Allen HD, Shaddy RE, Penny DJ, dkk, penyunting. Moss and Adams' heart disease in infants, children, and adolescents including the fetus and young adult. Edisi ke-9. Wolters Kluwer; 2017.h.3146-9.

8. Rørth R, Jhund PS, Yilmaz MB, dkk. Comparison of BNP and NT-proBNP in patients with heart failure and reduced ejection fraction. Circ Hear Fail 2020;13:1-10.

9. Derlene F, Mary R, Silva L, dkk. Neutrophil - to lymphocyte ratio used as prognostic factor marker for dilated cardiomyopathy in childhood and adolescence. Ann Pediatr Cardiol 2019;18-24.

10. Buyukoflaz $\mathrm{H}$. The neutrophil-lymphocyte ratio and plateletlymphocyte ratio acute rheumatic fever in children with cardiac involvement. Ann Clin Anal Med. Diakses: 5 Oktober 2021. Didapat dari: http://bayrakol.org.

11. Lilyasari O, Prakoso R, Kurniawati Y, dkk. Clinical profile and management of rheumatic heart disease in children and young adults at a tertiary cardiac center in Indonesia. Front Surg 2020;7:1-9.

12. Sika-Paotonu D, Beaton A, Raghu A, Steer A, Carapetis J. Acute rheumatic fever and rheumatic heart disease [Internet]. University of Oklahoma Health Science Centre. Diakses: 5 Oktober 2021. Didapat dari: https://www.ncbi.nlm.nih.gov/books/NBK425394/.

13. Beaton A, Aliku T, Dewyer A, dkk. Latent rheumatic heart disease: Identifying the children at highest risk of unfavorable outcome. Circ AHA 2018;176:139-48.

14. Durmus E, Kivrak T, Gerin F, Sunbul M, Sari I, Erdogan O. Neutrophil-to-lymphocyte ratio and platelet-to-lymphocyte ratio are predictors of heart failure. Arq Bras Cardiol 2015;105:606-13.

15. Loof TG, Sohail A, Bahgat MM, dkk. Early lymphocyte loss and increased granulocyte/lymphocyte ratio predict systemic spread of Streptococcus pyogenes in a mouse model of acute skin infection. Front Cell Infect Microbiol 2018;8:1-9.

16. Giray D, Hallioglu O. Are there any novel markers in acute rheumatic fever: Neutrophil-to-lymphocyte ratio, platelet-tolymphocyte ratio, and monocyte-to-lymphocyte ratio. Cardiol Young 2020;30:717-21.

17. Lenz AM. Natriuretic peptides in children: Physiology and clinical utility. Curr Opin Pediatr 2011;23:452-9.

18. Rusconi PG, Ludwig DA, Ratnasamy C, dkk. Serial measurements of serum NT-proBNP as markers of left ventricular systolic function and remodeling in children with heart failure. Am Heart J 2010;160:776-83. 